\title{
Variation in the erythrocyte size among larvae, juveniles and adults of Hypsiboas cordobae (Anura, Hylidae)
}

\author{
Mariana Baraquet*, Nancy Edith Salas, Adolfo Ludovico Martino \\ Ecología, Departamento de Ciencias Naturales, Facultad de Ciencias Exactas, Físico-Químicas y Naturales, Universidad Nacional de Río Cuarto, \\ Córdoba, Argentina. \\ * Correspondence: Ecología, Departamento de Ciencias Naturales, Facultad de Ciencias Exactas, Físico-Químicas y Naturales, Universidad \\ Nacional de Río Cuarto. Ruta Nacional N 36 - km 601, (X5804BYA) Río Cuarto, Córdoba, Argentina. Phone: +54 3584676167 , \\ Fax: +54358 4676230, E-mail: mbaraquet@exa.unrc.edu.ar
}

Received: 29 November 2012; received in revised form: 31 May 2013; accepted: 18 June 2013.

We aimed at determining sizes and shape of erythrocytes and evaluating the differences among larva, juvenile and adult Hypsiboas cordobae. Length and width of 40 randomly chosen erythrocytes and their respective nuclei from individuals of different ages collected in the experimental field "Las Guindas" (Córdoba, Argentina) were measured. Erythrocyte and nuclear areas were estimated assuming an ellipsoidal shape, and the aspect ratio, which reflects the shape of the cell, was calculated. The erythrocytes were oval, and their nuclei were also oval and centrally located. Erythrocyte size increased with age, whereas nuclei were larger in tadpoles than in juveniles. The cell and nucleus shapes also changed with age from the spherical shape in larvae to the more ellipsoidal one in adults. Discriminant analysis confirmed the existence of highly significant $(P<0.0001)$ differences in erythrocyte and nuclear areas among larvae, juveniles and adults, with a classification rate of $93.33 \%$.

Key words: age-related differences; erythrocyte; haematology; Hypsiboas cordobae.

Variación en el tamańo de los eritrocitos entre larvas, juveniles y adultos de Hypsiboas cordobae (Anura, Hylidae). Determinamos el tamaño y forma de los eritrocitos de Hypsiboas cordobae, evaluando las diferencias entre larvas, juveniles y adultos. Medimos la longitud y anchura de 40 eritrocitos seleccionados aleatoriamente en individuos de diferentes edades colectados en el campo experimental "Las Guindas" (Córdoba, Argentina). Estimamos las áreas de los eritrocitos y de sus núcleos asumiendo formas elipsoidales, y calculamos la razón de aspecto, indicativa de la forma de la célula. Tanto los eritrocitos como los núcleos mostraron forma ovalada, apareciendo los últimos en posición central. El tamaño de los eritrocitos aumentó con la edad, mientras que los núcleos fueron mayores en larvas que en juveniles. Las formas tanto de la célula como del núcleo también cambiaron con la edad, siendo esféricas en larvas y más ovaladas en adultos. Mediante un análisis discriminante confirmamos la existencia de diferencias altamente significativas $(P<0.0001)$ entre larvas, juveniles y adultos en las área de eritrocitos y núcleos, con una tasa de clasificación del $93.33 \%$.

Key words: diferencias relacionadas con la edad; eritrocitos; hematología; Hypsiboas cordobae.

The majority of studies in haematology of anurans are limited to blood cell counts (ATATÜr et al., 1998, 1999; DÖNMEZ et al., 2009) and erythrocyte size determination (Hartman \& Lessler, 1964; Matson, 1990; ATATÜR et al., 1998, 1999, 2001; ZHELEV et al., 2006; GAO et al., 2007;
GRENAT et al., 2009A,B), while studies on cell size variation among larvae, juveniles and adults are very scarce. One of the most important functions of erythrocytes is to carry oxygen and carbon dioxide, and their size and shape are indicators of the area available for gas exchange. For instance, a small 
erythrocyte possesses a comparatively greater rate of exchange than a large one. The study of erythrocytes in different species provides an interesting comparison of the erythrocyte size in relation to activity and habitat (HartMan \& Lessler, 1964; MartíneZ et al., 1985; SEVINÇ et al., 2000; WOJTASZEK \& ADAMOWICZ, 2003). Amphibians show an extensive range in erythrocyte sizes, being these relatively large in comparison with other vertebrates (DUELLMAN \& TRUeb, 1994; Gregory, 2001; CAMPBell, 2004, 2012).

Little is known about the relationship between ontogenetic growth and erythrocyte size, which could be relevant to organism biology especially in animals such as amphibians that have indeterminate growth (DAVIS, 2008; ARIKAN \& ÇIÇEK, 2011). Amphibian larval growth and metamorphosis have effects on blood cells such as erythrocytes (DAVIS, 2009; DAS \& MAHAPATRA, 2012). As part of the changes happening during metamorphosis involving the substitution of specific larval organs or cells by adult ones (OHMURA \& WAKAHARA, 1998), larval erythrocytes are replaced by adult ones (DORN \& BROYLES, 1982; YAMAGUCHI \& WAKAHARA, 1997; TAMORI \& WAKAHARA, 2000; WAKAHARA \& YAMAGUCHI, 2001). Consequently, larval and adult erythrocytes differ in size and morphology, being large and elongated in larvae and smaller and rounder in adults (BENBASSAT, 1974; DAVIS, 2008).

In the present paper we examine and evaluate differences in morphology and size of erythrocytes of larvae, juveniles and adults Hypsiboas cordobae (Barrio, 1965). Hypsiboas cordobae is restricted to highlands of Córdoba and San Luis provinces, in central Argentina (BARRIO, 1965; FAIVOVICH et al., 2004). This restricted distribution with a broad altitudinal range, its consideration by the IUCN Red List of Threatened Species as a taxon of Data Deficient, and the lack of information about its haematology make it an interesting species for study.

A total of 46 individuals of $H$. cordobae were collected from the experimental field "Las Guindas" (Alpa Corral, province of Córdoba, Argentina, 32³5’35.22” S, 64042'38.92"W; $930 \mathrm{~m}$ above sea level) in October and November months between 2007 and 2009. These included 15 tadpoles in stages 35 to 39 according to GOSNER (1960), 10 recently metamorphosed individuals (hereafter juveniles) with the tail completely reabsorbed obtained from captive-raised larvae, and 21 adults. Blood samples were obtained by angularis vein puncture in juveniles and adults (NöLLER, 1959), and directly from the heart after anaesthesia via immersion in $1 \%$ tricaine methanesulfonate in larvae. Smears of fresh blood were air-dried and stained with a $10 \%$ solution of Giemsa for $5 \mathrm{~min}$. Slides were observed under a trinocular microscope Primo Star (Pack 5) and the image processing software AxioVision 4.8 (Carl Zeiss, Oberkochen, Germany). The photographs were used to measure erythrocytes with Adobe Photoshop 9.0 (Adobe Systems, San Jose, California, USA). On each blood smear, length (L) and width (W) of 40 randomly chosen erythrocytes and their respective nuclei were measured using a scale of 20 microns as a reference. Erythrocyte and nuclear areas were calculated assuming an ellipsoid shape according to the formula $\mathrm{L} x$ $\mathrm{W} x \pi / 4$. We compared each variable among larvae, juveniles and adults using analyses of the variance (ANOVAs) followed by Tukey's 
HSD post hoc comparisons. Then, we used a discriminant function analysis to know the variables that better defined the variation among these groups.

Adult individuals showed the largest erythrocyte and nucleus areas (Table 1; Erythrocyte area: $\mathrm{F}_{2,43}=35.69, P<0.0001$. Nucleus area: $\left.\mathrm{F}_{2,43}=9.13, P=0.0005\right)$. Larval nuclei were larger than juvenile ones, whereas the opposite was true for erythrocyte size (Table 1), although in the latter case differences among age groups were not significant. The L / W ratio results revealed significant differences among age groups in shape of both erythrocytes $\left(\mathrm{F}_{2,43}=5.48, P=0.0077\right)$ and nucleus $\left(\mathrm{F}_{2,43}=43.05, P<0.0001\right)$. For both parameters, adults showed oval or elliptical shapes while in larvae they were rounder or more spherical (L / W closer to one, Table 1). In juveniles, erythrocyte shape was similar as in larvae while nucleus shape resembled that of adults.

Discriminant analysis based on length and width of erythrocytes and nuclei yielded two highly significant functions $(P<0.0001)$. The first function, with an eigenvalue of 6.12, explained $89.26 \%$ of the observed variation. The high canonical correlation
(0.92715) indicated a high weight of the function, while the low Wilks' Lambda (0.08084) indicated that the two selected variables (length and width of nuclei) were appropriate for discriminating age groups (Fig. 1). A total of $93.33 \%$ of the cases was correctly classified (100\% of larvae, $90 \%$ of juveniles and $90.48 \%$ of adults).

Our results showing differences in erythrocyte and nuclear size and shape among larvae, juveniles and adults agree with previously reported differences between larval and adult erythrocytes in amphibians. Many studies report that during metamorphosis, larger and elongated erythrocytes of larvae are replaced by smaller and rounder cells in adults (BENBASSAT, 1974; BROYLES, 1981; Dorn \& Broyles, 1982; Duellman \& Trueb, 1994; Yamaguchi \& WaKahara, 1997, 2001; HASEBE et al., 1999; DAVIS, 2008; ARIKAN \& ÇIÇEK, 2011; CAMPBELL, 2012). However, we observed that the erythrocyte and nuclear sizes in larvae were smaller than in adults, and that both cells and nuclei were more elongated in adults than in larvae. Our results are in agreement with those by YAMAGUCHI \& WAKAHARA (1997) in the salamander Hynobius retardatus, who found

Table 1: Mean \pm standard deviation of erythrocyte and nuclear measurements of larvae $(\mathrm{N}=15)$, juveniles $(\mathrm{N}=10)$ and adults $(\mathrm{N}=21)$ of Hypsiboas cordobae. Lower case letters indicate different groups defined by post hoc tests $(\mathrm{P}<0.05)$. Lar = Larvae; Juv = Juveniles; Adu = Adults.

\begin{tabular}{|c|c|c|c|c|c|c|c|c|}
\hline & \multicolumn{4}{|c|}{ Erythrocytes } & \multicolumn{4}{|c|}{ Nuclei } \\
\hline & $\mathrm{L}(\mu \mathrm{m})$ & $\mathrm{W}(\mu \mathrm{m})$ & $A\left(\mu m^{2}\right)$ & $\mathrm{L} / \mathrm{W}$ & $\mathrm{L}(\mu \mathrm{m})$ & $\mathrm{W}(\mu \mathrm{m})$ & $\mathrm{A}\left(\mu \mathrm{m}^{2}\right)$ & $\mathrm{L} / \mathrm{W}$ \\
\hline Lar & $20.47 \pm 1.00$ & $13.90 \pm 0.45$ & $223.98 \pm 16.71^{a}$ & $1.48 \pm 0.05$ & $8.22 \pm 0.33$ & $6.07 \pm 0.19$ & $39.26 \pm 2.51^{b}$ & $1.39 \pm 0.11$ \\
\hline Juv & $20.87 \pm 0.84$ & $13.69 \pm 0.58$ & $224.73 \pm 12.13^{a}$ & $1.53 \pm 0.10$ & $8.40 \pm 0.63$ & $5.03 \pm 0.59$ & $33.38 \pm 5.88^{a}$ & $1.69 \pm 0.13$ \\
\hline Adu & $23.66 \pm 1.14$ & $15.06 \pm 1.05$ & $280.58 \pm 28.22^{\mathrm{b}}$ & $1.58 \pm 0.10$ & $9.92 \pm 0.83$ & $5.55 \pm 0.64$ & $43.57 \pm 7.91^{c}$ & $1.80 \pm 0.14$ \\
\hline
\end{tabular}


Plot of Discriminant Functions

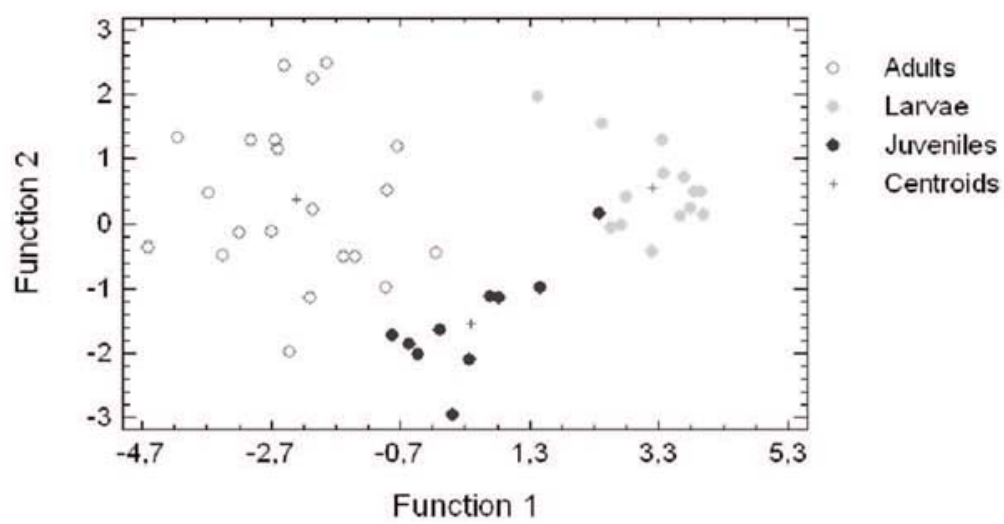

Figure 1: Representation of the first two canonical functions from the discriminant analysis performed on erythrocyte and nucleus variables of larvae, juveniles and adults of Hypsiboas cordobae.

larger erythrocytes in adults than in larvae. Furthermore, these authors also showed that in larvae, erythrocyte shape is round or spherical while in adults is oval or elliptical, and indicated that during the transition, erythrocytes showed an intermediate form between typical larval and adult cells, which also coincides with what we have observed in H. cordobae.

Because erythrocytes are responsible for storing and transporting oxygen (HARTMAN \& LESSLER, 1964) their characteristics determine in part the efficiency of this transport from respiratory systems to tissues (Holland \& Forster, 1966). Thus, amphibian erythrocyte size relates to the respiratory needs of the individuals (ARSERIM \& MERMER, 2008), and therefore increasing the amount of hemoglobin per cell, as it would happen in larger erythrocytes, would be one way to meet the body's increasing demands for oxygen as individuals grow in size. However, DAvis et al. (2009) argued that the increased size of erythrocytes with growth might merely reflect the allometric scaling of body and cells (i.e. as capillary size grows, cell sizes increase).

The age-related variation in erythrocyte morphology clearly warrants further studies to clarify the physiological mechanism involved and the implications of these changes. Our results may be helpful as reference values for future investigations and could also be used in combination with other hematological parameters for the study about the changes that occur in blood cells during metamorphosis and identifying hematopoietic organs in $H$. cordobae.

\section{Acknowledgement}

The first two authors thank the National Scientific and Technical Research Council (CONICET) for support. The Secretary of Science and Technology of National University of Río Cuarto (SECyT-UNRC) provided funds by Grant PPI $18 \mathrm{C} / 225$. We thank P. Grenat and J. Valetti for their help in the field and sample. Our study was authorized by Cordoba Environmental Agency (A.C.A.S.E.). 


\section{REFERENCES}

Arserim, S.K. \& Mermer, A. (2008). Hematology of the Uludag frog, Rana macrocnemis Boulenger, 1885 in Uludağ National Park (Bursa, Turkey). Ege Üniversitesi Su Ürünleri Dergisi 25: 39-46.

ARIKAN, H. \& ÇIÇEK, K. (2011). Changes in blood-serum proteins, erythrocyte count, and size of Pelophylax bedriagae (Camerano, 1882) during metamorphosis (Anura: Ranidae). Herpetozoa 24: 3-11.

Atatür, M.K.; Arikan, H. \& Mermer, A. (1998). Erythrocyte sizes of some Urodeles from Turkey. Turkish Journal of Zoology 22: 89-91.

ATATÜR, M.K.; ArikAn, H. \& ÇEviK, İ.E. (1999). Erythrocyte sizes of some anurans from Turkey. Turkish Journal of Zoology 23: 111-114.

AtATÜr, M.K.; Arikan, H.; ÇeVIK, İ.E. \& Mermer, A. (2001). Erythrocyte measurements of some Scincids from Turkey. Turkish Journal of Zoology 25: 149-152.

BARRIO, A. (1965). Las subespecies de Hyla pulchella Duméril y Bibron (Anura, Hylidae). Physis 25: 115-128.

Benbassat, J. (1974). The transition from tadpole to frog haemoglobin during natural amphibian metamorphosis. I. Protein synthesis by peripheral blood cells in vitro. Journal of Cell Science 15: 347-357.

BROYLES, R.H. (1981). Changes in the blood during amphibian metamorphosis, In L.I. Gilbert \& E. Frieden (eds.) Metamorphosis. A Problem in Developmental Biology. Plenun Press, New York, pp. 461-490.

Campbell, T.W. (2004). Hematology of Lower Vertebrates. American College of Veterinary Pathologists \& American
Society for Veterinary Clinical Pathology, Middleton, Wisconsin, USA.

Campbell, T.W. (2012). Hematology of amphibians, In M.A. Thrall, G. Weiser, R. Allison \& T.W. Campbell (eds.) Veterinary Hematology and Clinical Chemistry, $2^{\text {nd }}$ ed. Wiley-Blackwell, Ames, Iowa, pp. 313-317.

DAS, M. \& Mahapatra, P.K. (2012). Blood cell profiles of the tadpoles of the Dubois's tree frog, Polypedates teraiensis Dubois, 1986 (Anura: Rhacophoridae). Scientific World Journal 2012: 701746.

DAVIS, A.K. (2008). Ontogenetic changes in erythrocyte morphology in larval mole salamanders, Ambystoma talpoideum, measured with image analysis. Comparative Clinical Pathology 17: 23-28.

DAVIS, A.K. (2009). Metamorphosis-related changes in leukocyte profiles of larval bullfrogs (Rana catesbeiana). Comparative Clinical Pathology 18: 181-186.

Davis, A.K.; Milanovich, J.R.; DeVore, J.L. \& MAERZ, J.C. (2009). An investigation of factors influencing erythrocyte morphology of red-backed salamanders (Plethodon cinereus). Animal Biology 59: 201-209.

Dönmez, F; TosunoĞLu, M. \& GÜL, Ç. (2009). Hematological values in hermaphrodite, Bufo bufo (Linnaeus, 1758). NorthWestern Journal of Zoology 5: 97-103.

Dorn, A.R. \& Broyles, R.H. (1982). Erythrocyte differentiation during the metamorphic hemoglobin switch of Rana catesbeiana. Proceedings of the National Academy of Sciences 79: 5592-5596.

Duellman, W.E. \& Trueb, L. (1994). Biology of Amphibians. The John Hopkins University Press, Baltimore, Maryland, USA. 
Faivovich, J.; García, P.C.A.; Ananias, F.; Lanari, L; Basso, N.G. \& WheEler, W.C. (2004). A molecular perspective on the phylogeny of the Hyla pulchella species group (Anura, Hylidae). Molecular Phylogenetics and Evolution 32: 938-950.

GaO, Z.; WanG, W.; ABBAS, K.; ZhOU, X.; YANG, Y.; DiANA, J.S.; WANG, H.; WANG, H.; LI, Y. \& SuN, Y. (2007). Haematological characterization of loach Misgurnus anguillicaudatus: Comparison among diploid, triploid and tetraploid specimens. Comparative Biochemistry and Physiology A 147: 1001-1008.

GosNer, K.L. (1960). A simplified table for staging anuran embryos and larvae. Herpetologica 16: 183-190.

Gregory, T.R. (2001). The bigger the Cvalue, the larger the cell: genome size and red blood cell size in vertebrates. Blood Cells, Molecules, and Diseases 27: 830-843.

Grenat, P.R.; Bionda, C.; Salas, N.E. \& Martino, A.L. (2009a). Variation in erythrocyte size between juveniles and adults of Odontophrynus americanus. Amphibia-Reptilia 30: 141-145.

Grenat, P.R.; Salas, N.E. \& Martino, A.L. (2009b). Erythrocyte size as diagnostic character for the identification of live cryptic Odontophrynus americanus and O. cordobae (Anura: Cycloramphidae). Zootaxa 2049: 67-68.

Hartman, F.A. \& Lessler, M.A. (1964). Erythrocyte measurements in fishes, amphibia, and reptiles. Biological Bulletin 126: 83-88.

Hasebe, T.; Oshima, H.; Kawamura, K. \& KiKUYAMA, S. (1999). Rapid and selective removal of larval erythrocytes from systemic circulation during metamorphosis of the bullfrog, Rana catesbeiana. Development, Growth \& Differentiation 41: 639-643.

Holland, R.A.B. \& Forster, R.E. (1966). The effect of size of red cells on the kinetics of their oxygen uptake. Journal of General Physiology 49: 727-742.

Martínez, F.J.; Mendiola, P. \& De Costa, J. (1985). Parámetros hematológicos de Rana perezi (Amphibia: Salientia). Anales de Biología 5: 73-78.

Matson, T.O. (1990). Erythrocyte size as a taxonomic character in the identification of Ohio Hyla chrysoscelis and H. versicolor. Herpetologica 46: 457-462.

NölleR, H.G. (1959). Eine einfache Technik der Blutentnahme beim Frosch. Pflüger's Archiv für die Gesamte Physiologie des Menschen und der Tiere 269: 98-100.

OHMURA, H. \& WaKahara, M. (1998). Transformation of skin from larval to adult types in normally metamorphosing and metamorphosis-arrested salamander, Hynobius retardatus. Differentiation 63: 237-246.

SEVInÇ, M.; UĞURTAŞ, I.H. \& YILdirimHAn, H.S. (2000). Erythrocyte measurements in Lacerta rudis (Reptilia, Lacertidae). Turkish Journal of Zoology 24: 207-209.

TAMORI, Y. \& WAKAHARA, M. (2000). Conversion of red blood cells (RBCs) from the larval to the adult type during metamorphosis in Xenopus: specific removal of mature larval-type RBCs by apoptosis. International Journal of Developmental Biology 44: 373-380.

WaKahara, M. \& YAMAgUCHI, M. (2001). Erythropoiesis and conversion of RBCs and hemoglobins from larval to adult type during amphibian development. Zoological Science 18: 891-904. 
WojTASzeK, J. \& AdAMOWicz, A. (2003). Haematology of the fire-bellied toad, Bombina bombina L. Comparative Clinical Pathology 12: 129-134.

YAMAGUCHI, M. \& WAKAHARA, M. (1997).

Hemoglobin transition from larval to adult types occurs within a single erythroid cell population during metamorphosis of the salamander Hynobius retardatus. International Journal of Developmental Biology 41: 581-589.
YamaGuChI, M. \& WaKahara, M. (2001). Contribution of ventral and dorsal mesoderm to primitive and definitive erythropoiesis in the salamander Hynobius retardatus. Developmental Biology 230: 204-216. Zhelev, Z.M.; ANGelov, M.V. \& Mollov, I.A. (2006). A study of some metric parameters of the erythrocytes in Rana ridibunda (Amphibia: Anura) derived from an area of highly developed chemical industry. Acta Zoologica Bulgarica 58: 235-244. 